\title{
"Difficult Conversations across Religions, Race and Empires: American Women Missionaries and Japanese Christian Women during the 1930s and 1940s"
}

\author{
Noriko Ishii \\ Sophia University \\ norikokishii@sophia.ac.jp
}

\begin{abstract}
This essay examines how American and Japanese women in the foreign missionary movement struggled to reconcile the rise of state Shintoism, Japanese patriotic nationalism, and American racism and nationalism with their Christian faiths during the 1930 s and 1940s when the United States and Japan were moving towards war. It applies Kris Manjapra's notion of "aspirational cosmopolitanism" as the conceptual framework in its exploration of how an American woman missionary and her Japanese convert developed different visions of egalitarian cosmopolitanism and remained faithful to their Christian faiths as the states of Japan and the United States demanded more conformity to their wartime notions of patriotism. Charlotte B. DeForest, the last missionary president of Kobe College, who struggled with the questions of shrine visits and racism against Japanese Americans, managed to shape a new hybrid identity as Christian and "supernational." Takeda (Cho) Kiyoko, her former student, finally identified a Japanese dual consciousness through the image of "humans in shells" - a clue to another cosmopolitan vision rooted in Christian faith appropriate to Japanese culture in reconciliation with Asia.
\end{abstract}

\section{Keywords}

American women missionaries - Japanese women converts - World War II - Japan YWCA - shrine visits - Manzanar - Kobe College - Charlotte B. DeForest - Takeda (Cho) Kiyoko - Yuasa Hachiro 
In 1942, after Japan's attack on Pearl Harbor ignited war with the United States, Takeda Kiyoko, a 24-year-old Japanese exchange student from Kobe College, visited Charlotte B. DeForest, her 62-year-old missionary teacher, in Aubundale, Massachusetts. Together, they walked among the pine trees for a long prayer then bid each other goodbye and, in June, Takeda returned to Japan on board the last exchange ship. During the 1930s, antagonism between Japan and the United States had been increasing, producing an unprecedented challenge for the American women's foreign missionary movement in Japan. Racism against Japanese immigrants in the United States had been rising and Japanese militarists were claiming to represent the Asian people in their conflicts with white and Western imperialists based on race. The two nations appeared headed for war. It was in this context that American and Japanese women of the missionary enterprise struggled to craft a Christian community that could transcend differences of race and nation-state.

This article focuses its attention on two women, one American, one Japanese, who travelled along transnational missionary networks that took them across multiple national boundaries in Asia, Europe, and the United States. It discusses the process of their efforts to imagine and formulate more egalitarian and ecumenical relationships from the perspective of teacher and student, both seeking to find a Christian way to move ahead in nation-states on a road to war. For its conceptual framework, the examination that follows will draw on Kris Manjapra's notion of cosmopolitanism. Manjapra defines "aspirational cosmopolitanism" as "the pursuit of conversations across lines of difference ... that provisionally created shared public worlds." The interaction of these two women, as the following pages will demonstrate, affirms the usefulness of this model, as they sought equality across differences in their struggle to find grounding for their religious beliefs in a time when their countries were at war.

Building on these perspectives, this article explores the impact of war on the Christian thoughts of Charlotte B. DeForest (1879-1973), an influential American missionary educator in Japan, and Takeda (Cho) Kiyoko (1917-), her former student and a leading female Christian scholar. Examining these two women provides insights on how people conceived, circulated, and transformed notions of cosmopolitanism, as well as clarifying the relationship between cosmopolitanism and nationalism. Drawing on missionary correspondence, publications, and oral history interviews, its central argument holds that the cultural contact in missionary enterprises fostered hybrid understandings of cultures, as war provided momentum for women in mission to consider the

1 Sugata Bose and Kris Manjapra (eds.), Cosmopolitan Thought Zones: South Asia and the Global Circulation of Ideas (New York: Palgrave Macmillan, 2010), 5 . 
relationship between their loyalty to nation and to religion. Of course, despite their ideals, they could not prevent war and struggled to remain faithful to their vision in response to governments both suspicious of their transnational affiliations and eager to harness their expertise to achieve wartime goals. By embracing the power of observation and radical empathy, both crafted ingenious ways to subtly resist Western imperialism and Japanese colonialism and promote different kind of transnational activism.

Charlotte B. DeForest was born in 1879 in Osaka, Japan to a missionary family from the American Board of Commissioners for Foreign Missions (ABCFM). She became the last missionary president of Kobe College, a missionary women's school in Japan, serving from 1915 to 1940. Her upbringing as a missionary child in Japan until the age of 15 marked a significant imprint on her transnational experiences. Takeda remembers DeForest as an exceptional missionary, conversant in the Japanese language with a profound understanding of Japanese people and culture. ${ }^{2}$ In 1874, John H. DeForest, her father, had arrived in Japan. One of the pioneering American Board missionaries in country, he worked for the new mission stations in Osaka and Sendai. Those locations were already occupied competing with religions such as Buddhism, Shintoism, and rival Christian denominations, including British Anglican, Roman Catholic, and German Reformed Churches. From the beginning, John H. DeForest faced the challenge of balancing differences between himself and these competing groups. ${ }^{3}$

In her 1914 book drawing on her father's own writings, DeForest saw him demonstrating a "missionary evolution" during the 37 years of his missionary career, a result of "the interplay of the work and the environment." DeForest pointed to her father's efforts to use Japanese in his talks as evidence of his sensitivity to Japanese culture, and his communications with Buddhist priests

2 Author interviews with Takeda Kiyoko, 26 April 2013, 6 June 2013, Kawasaki, Japan.

3 Charlotte B. DeForest, The Evolution of a Missionary: A Biography of John Hyde DeForest for Thirty-Seven Year Missionary of the American Board in Japan (New York, Chicago, Toronto: Fleming H. Revell Company, 1914), 71-107; Motoi Yasuhiro, "Niijima jo to J.H. Deforesuto: rattorando kara sendai e," ["Niijima jo and J.H. DeForest: From Rutland to Sendai"], Kirisuto kyo shakai mondai kenkyu [The Study of Christianity \& Social Problems] 42 (July 1993): 56-82; Shigeru Yoshiki, "Chapter 4: Osaka dendo," ["Mission Work in Osaka"] in Amerikan bodo senkyoshi: kobe osaka kyoto suteshon wo chushin ni, 1869-189o nen [Missionaries of the American Board: With a Focus on Missionary Enterprises at Kobe, Osaka and Kyoto Stations, 1869189o], Doshisha daigaku jinbunkagaku kenkyujo [Doshisha University Institute for Study of Humanities and Social Sciences], ed. (Tokyo: Kyobunkan, 2004), 131-68; Toda Tetsuko, "Jon. H. Deforsuto to saikyo jikkai shinron" ["John H. DeForest and The True Argument on the Ten Commandments"], Yamanashi kenritsu joshi tankidaigaku kiyo [Bulletin of Yamanashi Prefectural Junior College for Women] $3^{1}$ (March 1998): 31-38.

4 DeForest, The Evolution of a Missionary, p. 7 . 
as evidence of his curiosity about Japanese religions. Gradually, he broadened his ecumenical understanding. Her father's all-inclusive projects were manyamong them the international and interdenominational construction of the first Young Men's Christian Association (YMCA) Hall in Osaka and famine relief work in Sendai in $1905 .{ }^{5} \mathrm{In}$ his writing, DeForest found compelling his recognition of "the good in Buddhism and Confucianism" and his idea that "the Old Testament absorbed many religious elements that belonged to other religions." He also said that "so-called ancestor worship" was "one of the best of preparations for the one great Ancestor of all men"-God himself. ${ }^{6}$ This final interpretation of ancestor worship resonated with DeForest's imagination when she later confronted the problem of shrine visits.

As Japan's military buildup proceeded and the tensions between the United States and Japan increased in the 1930s, the most challenging question that troubled DeForest as an American school administrator and a Christian missionary was whether she should or could take her students to the Shinto shrines in acts of reverence. This had been a controversial issue since the early $20^{\text {th }}$ Century when various Japanese government officials, fearing social unrest, actively began to promote "respect for deities and reverence for ancestors" to foster national morality. This was part of the process of the Japanese quest for national identity as a modern nation-state. As Carol Gluck shows, the Imperial Rescript on Education of 1890 gradually became enshrined as the national ethos that linked morality and patriotism. In this ethos, the emperor acquired dual roles as manifestations of both Confucian morality and Shinto divine lineage, and thus gained recognition as the core symbol that connected the two elements of national identity. ${ }^{7}$

In 1923, DeForest wrestled with these issues in her second book, The Woman and the Leaven in Japan, which she wrote as a textbook for local women's study groups. Here, she presented a skillfully balanced interpretation of how to reconcile Christian faith with the unsettling rise of Shintoism at the core of national education. DeForest interpreted the visits of her students to shrines as not religious but patriotic acts because the educational authorities had

5 Motoi Yasuhiro, "Niijima jo to J.H. Deforesuto: rattorando kara sendai e," ["Niijima jo and J.H. DeForest: From Rutland to Sendai"], Kirisuto kyo shakai mondai kenkyu [The Study of Christianity and Social Problems] 42 (July 1993): 64-71; M. William Steele, "Great Northern Famine of 1905-06: Two Sides of International Aid," Asian Cultural Studies 39 (March 2013): 4-15.

6 DeForest, The Evolution of a Missionary, pp. 242, 248.

7 Carol Gluck, Japan's Modern Myths: Ideology in the Late Meiji Period (Princeton, NJ: Princeton University Press, 1985), 102-103. 
claimed that "ceremonious reverence to the emperor" was a national duty. In addition, she pointed out that the Imperial Rescript did not conflict with Christ's teaching because it merely "embodies the ideals for national and individual character."

Yet in 1923, DeForest carefully delineated religious national holidays from secular ones and declared that Kobe College, as a mission school, would not observe the religious holidays of "the two equinoctial festivals for the worship of the imperial ancestors." As Japanese people in general did not consider the act of bowing or the act of reverence as religious, it would be no problem even if a Christian performed the act of reverence at the shrine or to the Imperial Portraits. ${ }^{9}$ She warned, however, that what was problematic with the Japanese in general was that they could not distinguish between God and deceased heroes and this would lead to animism and superstitions. But if they could acquire the Pauline gift of the "discerning of spirits," they would be able to distinguish between worshipping God and showing respect to the deceased. In this manner, DeForest developed an ecumenical understanding that "Japan's inheritance from the past may best promote the coming of the Kingdom of God."10 In fact, the Meiji Constitution of 1889 already had proclaimed religious freedom in Article 28. In the late $19^{\text {th }}$ Century, Shinto was divided into two categories - the rites of "Shrine Shinto" and "Sect Shinto" - the former corresponding to a unified national morality and the latter to religious freedom. Sarah Thal argues that because the government separated Shinto rituals from Shinto sects, "ensuing rhetoric continued to draw distinctions between worship as a public act and belief as private."11

Kate Nakai highlights such workings in her analysis of an episode in 1932, nine years after DeForest's book appeared in print. The Sophia UniversityYasukuni Shrine Incident began with several students refusing to show reverence at Yasukuni Shrine in the summer of $193^{2}$ because of their Catholic faith. The university defended its students on the ground of religious freedom, leading to the resignation in anger of the presiding military official at the institution. These events led to a crisis for Sophia University. Without the military

Charlotte B. DeForest, The Woman and the Leaven in Japan (West Medford, MA: The Central Committee on the United Study of Foreign Missions, 1923), 83, 73-74.

$9 \quad$ Ibid., pp. 83,85 .

$10 \quad$ Ibid., p. 85.

11 Sarah Thal, "A Religion That Was Not a Religion: The Creation of Modern Shinto in Nineteenth-Century Japan," in The Invention of Religion: Rethinking Belief in Politics and History, Derek Peterson and Darren Walhof, eds. (New Brunswick, NJ: Rutgers University Press, 2002), 100-14. 
official on faculty, it was destined to lose the privilege of students' exemption from military service, as well as a reputation that it was a patriotic institution. Facing such a crisis threatening the university's survival, Jean-Baptiste Chambon, the French Catholic archbishop in Tokyo, collaborated with the Ministry of Education to reinterpret the meaning of shrine visits as patriotic and not religious, a compromise the Vatican quickly endorsed in 1936 to ensure the school's existence. ${ }^{12}$ The Sophia University-Yasukuni Shrine Incident had "major repercussions" on other churches because by 1936, most of the Christian schools across Japan shared similar religious hardships.

What is striking about DeForest's judgment and action is that she had reached the same conclusion ten years before the French archbishop's decision in Tokyo. Presumably, she was uniquely able to make such an intelligent analysis because of her hybrid upbringing in Japan with a missionary father who pioneered an ecumenical understanding of Japanese religions. In addition, she herself had travelled and read widely, listened to national radio broadcasts of Japanese scholars' talks, and developed a profound understanding of Japanese religions and culture. ${ }^{13}$ DeForest had observed the rice planting ceremonies at the local Hirota shrine and visited historic shrines and hot springs in Owani in northern Japan. ${ }^{14}$ She read Daniel Clarence Holtom's 1938 book on Shintoism, entitled The National Faith of Japan: A Study of Modern Shinto and took meticulous notes on the diverse treatment of supreme deity in Shinto sects and how that differed from the worship of the sun goddess in State Shinto. ${ }^{15}$ With such firsthand research of Shinto rituals and beliefs, DeForest managed to develop a hybrid imagination to reconcile Christian faith with shrine visits,

12 Kate Wildman Nakai, "Coming to Terms with 'Reverence at Shrines': The 1932 Sophia University-Yasukuni Shrine Incident," in Kami Ways in Nationalist Territory: Shinto Studies in Prewar Japan and the West, Bernhard Scheid, ed. (Vienna, Austria: Austrian Academy of Sciences, 2013), 109-53.

13 Charlotte B. DeForest to Sarah DeForest Pettus and Louise DeForest, 23 October 1937, folder 6,Papers of Charlotte B. DeForest Papers, 1903-1960, Sophia Smith Collection [hereafter, ssc], box 1, Smith College, Northampton, MA.

14 Kanheitaisha Inari Jinja [Fushimi Inari Shrine], “Otaue matsuri shikishidai” “[Program of Rice Planting Ceremony"], June 1938 and Charlotte B. DeForest, "Flute and Drum Interlude between Singing of the Otaue Uta at Fushimi Shrine Rice Planting Ceremony," June 1938, folder 57, Papers of Charlotte B. DeForest, Record Group [RG] 178, box 4, Special Collections, Yale Divinity School Library [hereafter, YDSL]; Charlotte B. DeForest, "My Experience with Shinto," folder 29, box 2, ibid; Charlotte B. DeForest, "Rambles in Owani," folder 31, box 2, ibid.

15 Charlotte B. DeForest, "From Mr. Holtom's book, The National Faith of Japan," n.d., folder 57 , box 4 , ibid. 
resolving for the moment what later would become an impasse for Christian schools in Japan.

By the late 1930s, the Japanese government connected state Shintoism with a unified national morality and increasing controls began to affect academic freedom. For Christian liberals, the so-called Doshisha Incident of 1937 became a symbolic blow because it represented an outright attack of right-wing conservatives on Christian liberal thinking. Yuasa Hachiro, president of Doshisha University, resigned in December 1937, following right-wing politicians, militarists, journalists and even faculty colleagues staging attacks on him in disputes that initially had begun in June 1935. The rest of the campus community too attacked Yuasa for his liberal views, alleging that he was a national traitor. ${ }^{16}$ In March 1937, the Ministry of Education compiled and distributed the "Principles of National Polity" (kokutai no hongi) to all schools nationwide. The government's purpose was to pressure schools to spread the idea that the emperor held sovereign power and the emperor system constituted the core of national polity (kokutai) or Japanese national identity. Such steps manifested increasing governmental regulation of academic freedom. ${ }^{17}$ That July, the Sino-Japan War broke out.

By September 1937, the Japanese government enforced policies to mobilize the nation for the war effort. Accordingly, it required every governmentrecognized school to take its students to shrine visits every month to pray for victory in the Sino-Japan War. This time, tensions intensified because DeForest faced the serious problem of being required to send her students to the shrines regularly. She knew that officially Japanese considered Christian religion and shrine visits to be compatible; the Japanese government declared that "this national cult was not a religion." At the same time, DeForest herself understood that Shintoism "indubitably contained elements that [many] considered religion." Facing such difficulties, DeForest's private letters to her sisters in October 1937 revealed that what released her from final emotional anguish was "a sense of revelation" that "Shinto is the Judaism of Japan, the tutor to bring the nation to Christ." She confessed that emotionally, she did not want to go to the shrine, but "was led to overcome that feeling" because it was "an act of sympathetic

16 Kiyoko Takeda Cho, Hachiro Yuasa: The Hopes and Challenges of a Christian Educator in Japan (Norwalk, CT: East Bridge, 2008), 39.

17 Komagome Takeshi, "Senjika doshisha saiko: teikokushi no shiten kara," ["Reconsidering the History of Doshisha during the 1930s: From the Perspective of Japanese Imperial History"], Doshisha University Institute for Humanities and Social Sciences, ed., Kirisutokyo shakaimondai kenkyu [The Study of Christianity and Social Problems] 62 (December 2013): 103-34. 
self-identification with the people" she served. Moreover, DeForest believed that "God is carrying out a process of progressive purification of Shinto into a religion of Christian characteristics." She also said that "it was her father's spirit that was communicating" and "he might do it if he were here now."18 As these confessions reveal, for DeForest, her conviction that this was God's plan sustained her during the difficult times prior to the outbreak of war between Japan and the United States.

By October 1937, the act of receiving the gift of Imperial Portraits in a fireproof repository at the educational institutions became a symbolic sign to demonstrate the loyalty of the school to the government. Imperial Portraits were the official photographs of the emperor and the empress. Although DeForest implied her underlying resistance to accepting the pictures in her 1923 book, she finally relented and received the Imperial Portraits in December 1937. Knowing that somebody within Kobe College might steal them to harm her school, she slept next to the Imperial Portraits. "I am spending the night in my presidential office," she recorded, "as the honorable night guardian of the Imperial Portraits that we received yesterday."19

Finally, however, DeForest's discovery a year later of the massive scale of atrocities when Japanese forces occupied Nanjing in December 1937 inflicted a devastating blow on her that far exceeded her tolerance. The prior September, the Japanese military had issued military censorship and propaganda guidelines for publications on battle results in northern China, emphasizing the reporting of victories and concealing of defeats. As Jon T. Davidann has pointed out, such censorship effectively kept the Japanese public ignorant of what was actually happening in the Sino-Japan War. ${ }^{20}$ Therefore, when the local government asked Kobe College to join the flag procession in celebration of the fall of Nanjing, DeForest, unaware of the atrocities, "pocketed my personal feelings" and joined the procession as a college president. None of her missionary colleagues joined and they criticized her because celebrating victories "violated their consciences."21 "I probably would not have gone to the Nanking

18 DeForest to Sarah DeForest Pettus and Louise DeForest, 23 October 1937, folder 6, DeForest papers, box 1, ssc.

19 DeForest to Sarah DeForest Pettus, 19 December 1937, ibid.

20 Jon Thares Davidann, Cultural Diplomacy in U.s.-Japanese Relations, 1919-1941 (New York: Palgrave Macmillan, 2007), 199-200.

21 Sherwood F. Moran to Wynn C. Fairfield, 8 January 1938, vol. 61, ABC16.4.1, Papers of the American Board of Commissioners for Foreign Misisions, 1810-1961 [hereafter, ABCFM], Houghton Library, Harvard University [HLHU], Cambridge, MA. 
one," she later confessed, "if I had known at the time what I later learned about it."22

By November 1938, DeForest was able to read essays on the Nanjing atrocities in the July and October issues of Reader's Digest that accidently missed censorship or friends received enclosed in letters to them. Although she tried to share comforting stories she learned from her missionary colleagues in China about four Japanese army officers with bushido spirit who had committed suicide instead of following orders against their conscience, DeForest was devastated at her own conduct. In deep remorse, she received some comfort after reading a letter from Wynn C. Fairfield, a forgiving ABCFM secretary, who reassured her that "I am confident that the decisions you reached were the result of continued prayers for guidance."23 Thereafter, DeForest did not attend "any celebration for the fall of Canton or Hankow."24 In fact, when an Asahi newspaper reporter came for an interview and asked for her thoughts on the fall of Hankou, she actually broke into tears and only could reply "nothing to say" and "I feel so deeply the loss of life and the destruction of civilization." She later regretted that she allowed herself to be emotional and to pass up the opportunity to express her constructive viewpoint - a faith that God works through history and overrules men's mistakes and sins. ${ }^{25}$

Concurrently, the Japanese government's pursuit of thought control over civilians continued. In March 1938, the military police in Osaka, suspicious of Japanese Christians' vision of national polity and loyalty, requested written responses from 24 Japanese Christian educators and pastors on the question of how they understood the relationships between the emperor and Christian God and the Rescript of Education and the Bible. Dean Kawasaki Ichizo of Kobe College received the questionnaire and, after long faculty discussions, the administrators including Vice President Hatanaka Hiroshi prepared the answers that would be "as wise as serpents and as harmless as doves." Central to their response was the argument that emperor and Christian God were compatible, with the emperor being "present divinity" (akitumikami) and "visible human divinity" (arahitogami) and the Christian God representing "the universal spirit" (uchuteki seishin) and "the founder of Christianity." 6

\footnotetext{
22 DeForest to Sisters, 17 November 1938, ibid.

23 Fairfield to DeForest, 22 March 1938, vol. 53, ibid.

24 Takenaka Masao, Shi Bi Deforesuto no shogai: bi to ai no tankyu [The Life of C.B. DeForest: In Quest of Beauty and Love] (Osaka: Sogensha, 2003), 144-45; Charlotte B. DeForest, History of Kobe College (Kobe, Japan: Kobe College, 1950), 165.

25 DeForest to Sisters, 17 November 1938, vol. 61, ABC16.4.1, ABCFM papers, HLHU.

26 DeForest to Mrs. Wilson [sic], 13 March 1938, ibid.
} 
DeForest was concerned that this was contradictory with two absolutes, but the administrators' answers managed to convince the military police. ${ }^{27}$ DeForest worried that the modern Japanese Christian "tradition of bending rather than breaking" theological beliefs was creating Japanese Christianity and not the universal Christianity that she espoused..$^{28}$ Although she understood this as temporary, such compromise went beyond DeForest's scope of tolerance.

DeForest, whom colleagues perceived as most in need of a furlough but "the most determined to stay,"29 finally returned to the United States for health reasons in 1940. U.s. entry into World War II in December of the following year then forced her to remain there. After the United States declared war on Japan, President Franklin D. Roosevelt signed Executive Order 9066 in February 1942 that authorized the U.s. military to relocate nearly 120,000 Japanese Americans from the West Coast to ten internment camps west of the Mississippi River. In June, former missionaries in Japan of different Christian denominations convened in the Durham Council of Christian Churches, utilizing the missionary networks that had protested anti-Japanese sentiment in the United States after World War I. ${ }^{30}$ At this meeting, the participants organized "the Congregational Christian Committee for Work with Japanese Evacuees," as well as passing a resolution stating that "dispersion" of the Japanese Americans across the country was the best resettlement policy to combat racism. ${ }^{31}$

Many American missionaries returning from Japan during wartime became engaged in Japan-related work, including working in Japanese American internment camps and teaching Japanese to American soldiers. As Alice E. Cary, the Japan secretary at the ABCFM, explained, they could "use their knowledge of Japan and the Japanese language to ease the difficulties for both sides." ${ }^{32}$ For American Board missionaries alone, forty of 287 returned missionaries served in Japan-related works. ${ }^{33}$ Missionary networks including staff of the Young Men's Christian Association (YMCA) and Young Women's Christian

27 Kobe jogakuin [Kobe College], ed., Kobe jogakuin hyakunenshi sosetsu [Centennial History of Kobe College: General] (Kyoto: Kawakita insatsu, 1976), 227-31; DeForest, History of Kobe College, p. 171; Davidann, Cultural Diplomacy, pp. 191-92.

28 DeForest to Wilson, 13 March 1938, vol. 61, ABC16.4.1, ABCFM papers, HLHU.

29 Alice E. Cary to Dr. Wald [sic], 16 April 1940, vol. 69, ibid.

30 Izumi Hirobe, Japanese Pride, American Prejudice: Modifying the Exclusion Clause of the 1924 Immigration Act (Stanford, CA: Stanford University Press, 2001).

31 "The Congregational Christian Committee for Work with Japanese Evacuees," ABC85.5, ABCFM papers, HLHU.

32 Alice E. Cary, “Post-War Japan Bulletin,” No. 1, vol. 68, ABc16.4.1, ibid.

33 Fellowship of Christian Missionaries, Executive Committee, "Notes about Former Japan Missionaries," "An Occasional Newsletter for Returned Missionaries from Japan," March 
Association (YWCA) were instrumental in connecting returning missionaries with different projects associated with Japan.

In this context, DeForest, self-consciously chose jobs with connections to "humanitarian" instead of "military" appeals. ${ }^{34}$ Until April 1942, she plainly turned down offers for government positions, saying, for example, "my reply ... [to your request to undertake] translation work for National Defense must be negative" because of health reasons. ${ }^{35}$ Beyond July 1943, however, she learned to "be extremely careful" in the choice of her words when declining federal government job offers because she had suffered from an unhappy experience with the local papers that publicized her work in a way that could hurt her Japanese Christian friends residing in the United States and in Japan. They acclaimed her as "one of the world's greatest educators" who "was now enthusiastically" doing her part "to help with the war against Japan."36 Therefore, when the Office of Strategic Services, which later became the Central Intelligence Agency (CIA), asked DeForest to send in applications for translation work, DeForest wrote a lengthy letter asking if such work would "build a barrier" between her and her Japanese Christian friends. She further explained that she wanted to "fit into the place that will best contribute to the establishment of the Kingdom of Heaven." No records exist that DeForest submitted the application, suggesting that she pretended to be open, but obliquely shied away from the offer. ${ }^{37}$ Instead, she chose humanitarian jobs of interpreting and counseling for Japanese Americans at the East Boston Immigration Station and Manzanar Relocation Center (about 95 miles east of Fresno in California) and teaching Japanese to American soldiers. Among all her work, she was most passionate about the interpreting she did for military hearings at Boston and Manzanar.

The U.S. government was eager to use the knowledge of missionaries who had served in Japan, yet was skeptical of their allegiance. When a couple of Federal Bureau of Investigation (FBI) men summoned DeForest to check the accuracy of some Japanese documents, DeForest knew that this was "a camouflaged examination" and felt amused because she knew they were not

1944, Russell L. Durgin, ed., Young Women's Christian Association, New York, ABC85.5, ibid.

34 DeForest to Henry Griffin, 16 December 1942, folder 5, ABC 76, box 1, ibid.

35 DeForest to Thomas J. Slowie, Federal Communications Commission, 7 June 1941, folder 1, box 5 , ibid.

36 DeForest to Fairfield, 4 July 1943, folder 6, box 1 ibid.

37 Daniel C. Buchanan to DeForest, 29 January 1944, 8 February 1944, folder 10, box 1, ibid; DeForest to Buchanan, 4 February 1944, 4 March 1944, folder 7, ibid. 
one hundred per cent sure if they could trust her. ${ }^{38}$ This experience undoubtedly reinforced her commitment to humanitarian, rather than government, service during the war. DeForest's work as an interpreter at the East Boston Immigration Station from September 1942 to March 1943 in fact would give her "a great kick" as it was "distinctly a piece of social service." She discovered that humanitarian work was what she had sought as the focus of her energies while in the United States during the war. ${ }^{39}$ DeForest wrote in January 1943 that her "chief excitement last week was that the two Japanese whose hearings I had done a little interpreting at were released, the old man [an FBI (Federal Bureau of Investigation) case] on parole and the younger one [an immigration case] on bond." ${ }^{40}$ She told a colleague that she found these assignments rewarding because they provided "a very real opening for Christian social work."41

After finishing assisting all the Japanese Americans detained in Boston, DeForest decided to take a Japanese teaching job at Pomona College in Claremont, California beginning in April 1943 because she thought this was "humanitarian" work, even though it was clearly a "military project."42 The job was to teach and supervise a new nine-month program at the Army Student Training Unit in Foreign Areas and Languages. ${ }^{43}$ "Isn't it strange," she observed in sarcastically pointing to the contradiction, "to put a language project into a zone where real Japanese are not allowed even as teachers?" DeForest regarded educational work to be humanitarian because she thought she could broaden students' views of the Japanese people and Japanese culture. The purpose was to train "specialized soldiers" for work during the postwar U.s. occupation of Japan and, among her seventeen male students, six Nisei (born in the United States to parents who were immigrants from Japan) joined the U.s. military and served in occupied Japan. ${ }^{44}$

Confident that work at Japanese American internment camps would have "the priority over any other work that she knew of" because it met humanitarian

38 DeForest to Grace and Edith [sic], 16 November 1942 and DeForest to Griffin, 16, 22 December 1942, folder 5 , ibid.

39 DeForest to Susan Searle, 7 December 1942, ibid.

40 DeForest to Maud Pettus and William Winston Pettus, 17 January 1943, ibid. The former was Nakada Jujiro and the latter Nakamura Eitaro. Nakamura himself wrote thank you letters in Japanese to Charlotte B. DeForest. Nakamura Eitaro to DeForest, 16 January 1943, 6 March 1943, ibid.

41 DeForest to Esther Rhoades, 25 March 1944, folder 7, box 1, ibid.; O.S. Remington to DeForest, 9 January 1943, folder 13, ibid.

42 DeForest to Sarah DeForest Pettus and Louise DeForest, 10 March 1943, folder 6, ibid.

43 DeForest to Fairfield, 3 July 1943, ibid.

44 DeForest to Glenn Shaw, 7 March 1943, ibid. 
needs, DeForest took the job of junior counselor at the Family Counseling Program at Manzanar Relocation Center from June 1944 to December $1945 .{ }^{45}$ By June 1944, about half of the 11,00o internees at Manzanar already had relocated and thus her main job was to interview remaining families and dependents, seek available government aid, write reports, and make arrangements to help them relocate. ${ }^{46}$ She also assisted Japanese Americans and colleagues in translation, educational, and religious work. One of DeForest's chief contributions here was her negotiation of the placement of Japanese Americans outside the camp as language teachers at Stanford University. ${ }^{47}$

While at Manzanar, DeForest encountered again her old friend Yuasa Hachiro, who had resigned under duress as the president of Doshisha University in 1937. Yuasa visited Manzanar for a week in October 1944 as a member of the Preaching Mission that the Federal Council of Churches had sent to the camp. Here, he delivered talks on religion as "a Christian and world citizen" and as "a Japanese to Japanese" for the Issei (Japanese immigrants to the United States) internees. As "a Japanese to Japanese," he explained that the militarists gained control of Japan because "they were the only group that was working for the whole nation" and providing "national leadership." DeForest found him "very wise" in the way that he indirectly indicated how "he disapproved of the militarist policy, but did not openly condemn Japan." ${ }^{\text {8 }}$ She was impressed to see Yuasa stirring both non-Christians and Christians alike.

At the start of his well-attended talks, Yuasa introduced a God in Shintoism named Ameno ominaka nushi- "The Lord of the Great Heavens" - that adherents often described as "an invisible deity" who was "seven generations behind the sun-goddess Amaterasu." Then, as a Christian and world citizen, he asked the audience this question: "Is not He the same as the Creator, the one God, in the Christian Bible?" Yuasa continued that the two rites of the tea ceremony and the Last Supper in Christianity had several commonalities because they celebrated the same God. ${ }^{49}$ For DeForest, the highlight of Yuasa's presentation was the scope of his ecumenism. His imagination seemed to imply that he believed all religions shared one common origin in the same God, and therefore

\footnotetext{
45 DeForest to Buchanan, 4 March 1944, folder 7, ibid.

46 DeForest to Friends, 8 August 1944, ibid; Charlotte B. DeForest, Journal Entry, Manzanar, 4 February 1945, folder 6, box 2, ibid.

47 DeForest to Fairfield, 1 August 1944, folder 7, box 1; DeForest, Journal Entry, Manzanar, 26 October 1944, folder 5, box 2, ibid.

48 Ibid.

49 DeForest, Journal Entry, Manzanar, 21 October 1944 and 3 November 1944, folder 5, box 2, ibid.
} 
professed religious tolerance to all different religions, including Shintoism and Christianity. Yuasa's address made a strong impression on DeForest because his religious conception was far more flexible and wider than her own imagination that perceived Shintoism as a preparatory stage to Christianity.

Among all her work, what DeForest found most difficult and rewarding was the oral translating that she did for Japanese Americans who had to answer questions at military hearings about their deportation. In this venue, DeForest interpreted and became the mediator between two cultures. She explained to the military officers how different the notion of spirituality was in Japan and what emperor worship and prayer for the deceased really meant. ${ }^{50}$ The state of military hearings was in confusion because especially after the U.s. Supreme Court nullified a portion of the military exclusion order on 18 December 1944, the U.s. government lost legal grounds to keep American citizens in confinement without any charge and had to conduct individual exclusion hearings to determine the fate of individual internees. ${ }^{51}$ DeForest wrote that even with the news of the lifting of the west coast ban, both Nisei and Issei were wary and did not rush back to California for fear of discrimination in jobs and concerns about resuming their lives without any possessions. Instead, many tried to apply for repatriation because they thought that was the only way to stay in the internment camps and gain security for the family. ${ }^{52}$

DeForest believed that once the U.s. government lifted the exclusion ban, anyone who was a law-abiding citizen should be able to reside on the West Coast. But it did not turn out that way. The results of the military hearings were disturbing because the U.s. Army made ad hoc decisions to exclude 207 of Nisei men whom the War Relocation Authority (WRA) had cleared to relocate. This outcome terrified Japanese Americans and, in some cases, they answered "no" to the loyalty question because their families insisted that the only way to stay together was to return to Japan. ${ }^{53}$ Indignant over these developments, when Dillon S. Myer, director of WRA, visited Manzanar in February 1945, DeForest asked "by what authority the Army was excluding citizens without legal trials." As of 15 February 1945, 561 Manzanar internees had u.s. Army hearings and a total of 382 received judgments either definitely excluding or recommending

\footnotetext{
50 DeForest, Journal Entry, Manzanar, 23 March 1945, folder 6, box 2, ibid.

51 Mae M. Ngai, Impossible Subjects: Illegal Aliens and the Making of Modern America (Princeton, NJ: Princeton University Press, 2004), 188.

52 Ibid., pp. 188-89; DeForest Journal Entry, Manzanar, 29 December 1944, folder 5, ABC76, ABCFM papers, box 2, HLHU.

53 DeForest, Journal Entry, Manzanar, 4 February 1945, folder 6, АвС76, АвсFм papers, box 2, HLHU.
} 
their exclusion from resettlement outside the camps, even though 159 of them already had WRA clearances to relocate. ${ }^{54}$ Decisions at the U.s. Army hearings often occurred without any help of interpreters, resulting in many internees suffering from unjust allegations. In this context, DeForest's work as a mediator between the Japanese Americans and U.s. military officials was extremely important. Although she was only able to assist a fortunate few to relocate, some who received her help would play a significant role thereafter in broadening popular understanding of Japanese culture in the postwar United States.

On 25 March 1945, DeForest wrote that "yesterday and today I was called off from my usual work for a while to interpret for two military hearings of excludees before a galaxy of eight or ten officers." ${ }^{25}$ Of the two, the first hearing was most challenging because the man could not understand English. When it came to the hard questions of "the divinity of the Emperor" and "the enshrining of soldiers who die for their country," DeForest "demurred once or twice" because she could not find relevant Japanese expressions. This, she decided in retrospect, turned out to be "rather good" because it allowed her to gain another chance to describe the Japanese notion of spirituality. DeForest explained that Japanese were "much more conscious of spirits in their everyday life" and for Japanese "the 'deification' of soldiers after death" corresponded well to "the 'canonization' of the saints by the Catholic Church." "That," an officer said in response, "puts a rather different light on it." ${ }^{56}$ With this small victory, DeForest educated U.s. officials about Japanese culture and made a difference in the lives of vulnerable Japanese Americans.

The most notable of DeForest's work as an interpreter was when she served as a translator at the U.s. Army hearing for Buddhist priest Reverend Nagatomi Shinjo on 21 May 1945. The wRA officials wished for his relocation with his congregation to the Philadelphia area because they were convinced that he would be a great leader for resettling internees. If he built a Buddhist church there, his congregation would have farm and gardening opportunities. ${ }^{57}$ The hearing lasted for three and a half hours, and the crucial question was to clarify if he had any connection with the Japanese government as a Buddhist priest. DeForest managed to make it plain during the interpretation of the hearing that clergy of the Shin sect in the United States had organized the Buddhist Church of America "breaking entirely with the Honganji organization in Japan" in April of the previous year. Thus, with helpful support from the WRA officers

\footnotetext{
54 DeForest, Journal Entry, Manzanar, 20 March 1945, ibid.

55 DeForest, Journal Entry, Manzanar, 23 March 1945, ibid.

56 DeForest, Journal Entry, Manzanar, 23 March 1945, ibid.

57 DeForest, Journal Entry, Manzanar, 13 May 1945, ibid.
} 
who spoke as witnesses, DeForest succeeded in achieving "the best" military hearing "that I have yet attended" although it was "rather tense at times." ${ }^{\text {" }}$ In July 1945, Nagatomi happily reported to DeForest that he had received official clearance. Later in 1958, the priest became the Director General of the Federal Council of Buddhist Churches and his son Masatoshi became Harvard University's first full-time professor in Buddhist studies.

For DeForest at Manzanar, atomic bombings in Hiroshima and Nagasaki were "horrors beyond our conception." Experiencing war both in Japan and the United States, she wrote on 11 August 1945 that she was neither American nor Japanese but first and foremost Christian. She argued that "our religion should make us supernational," repeating the phrase "supernational" that Vice President Hatanaka at Kobe College had used in September 1937 when they discussed the Sino-Japan War. When DeForest asked Hatanaka "how we Christians could be international," he had replied "that he was supernational to the extent that he did not pray for the victory of Japanese army — tho' as a Japanese he desired it."59 By acting as a mediator between the two cultures both in Japan and the United States, DeForest managed to craft a cosmopolitan Christianity that transcended nation-state and became "supernational." In sum, DeForest demonstrated creative imagination through difference during the difficult wartime years on both sides of the Pacific, constructing a new multinational vision of Christian ecumenism that transcended differences of race, state and religion. This description of an emerging "aspirational cosmopolitanism" now turns to examination of how the war caused Takeda Kiyoko, DeForest's former student, to embark on a quest to craft a Japanese Christianity, a new ecumenical understanding that would fit Japanese culture with Asian Christianity in a spirit of reconciliation.

Takeda Kiyoko, born in 1917, entered ABCFM mission school of Kobe College in 1934. After five years of study and receiving baptism in 1938, she was a delegate to the Amsterdam World Conference for Christian Youth in the summer of 1939. By then, Takeda was a successful protégé of the prewar missionary initiatives in women's higher education in Japan. Thereafter, she studied abroad in the United States until the war broke out between the United States and Japan. Takeda returned to Japan in August 1942 and worked for the Japan YWCA student department during and after the war, which prepared her to become a leader in the postwar ecumenical movement and a leading scholar in Ethics and Religion at the International Christian University in Tokyo. She,

$5^{8}$ DeForest, Journal Entry, Manzanar, 21 May 1945, ibid.

59 DeForest, Journal Entry, Manzanar, 11 August 1945, ibid.; DeForest to Sarah DeForest Pettus, September 1937 of 1938, folder 6, DeForest papers, box 1, SsC. 
like DeForest, struggled to retain her cosmopolitan ecumenical beliefs in the context of a suspicious and aggressive state at war. ${ }^{60}$

It was Takeda's mother who influenced Takeda significantly in her choice to go to Kobe College and to study abroad. In her autobiography, she described her liaison with her mother as "an experience of an unexpected encounter with a dauntless Meiji-born woman."61 Takeda was born to a wealthy landowning family in Hiogo Prefecture but soon her widowed mother, a highly intellectual woman, was raising her alone. Takeda's mother had chosen marriage over a college education, but had developed critical ideas on labor issues after reading Crossing the Deathline (1920). Its author was Kagawa Toyohiko, a Christian social activist. Inspiring Takeda's mother to do this reading was hearing peasants gossip that her red silk crepe kimono symbolized their tears of blood. Thus, she repeatedly taught her daughter to become self-sufficient to avoid the landowner's sin of exploiting peasants' labor to make a living. She urged Takeda to go to Kobe College because Takeda would need religion to control her self-assertiveness and Kobe College would equip her with English skills that would enable her to access the world. ${ }^{62}$

Mission schools in Japan had become a driving force to expand women's opportunities and liberate females into modernity. Takeda's mother gave such advice precisely because of the unsettled context, with the Mukden Incident of September 1931 and the first stage of the Sino-Japan War, the ultra-nationalists' assassination of the prime minister in May $193^{2}$ and Japan's departure from the League of Nations in February 1933. Later in 1939, when Takeda received a scholarship offer to study abroad, her mother quickly endorsed Takeda's acceptance, saying that her daughter did not need to marry because marriages were worthless, an attitude that helped Takeda to make unconventional choices. ${ }^{63}$

Charlotte B. DeForest, the missionary president of Kobe College, inspired Takeda to begin to think about receiving baptism. Being baptized always had been a bold act in Japan because Japanese culture had embraced a longstanding skepticism about Christianity. One such manifestation was the Order Number Twelve the Ministry of Education issued in 1899 that forbade religious

\footnotetext{
6o "Takeda Kiyoko san, 'Deai ga ataete kureta shogai no shukudai”[“Ms. Takeda Kiyoko, Lifelong Homework Given by Encounters"], Ichizawa Hirari interviewer, Croissant 907 (August 2015): 20-23.

61 Takeda Kiyoko, Deai: hito, kuni, sono shiso [Encounters: People, Nation, Thoughts] (Tokyo: kirisutokyo shinbunsha, 2009), 16.

62 Ibid., pp. 9-10, 13-14.

63 Ibid., pp. $15^{-16 .}$
} 
education at any government-recognized schools. ${ }^{64}$ DeForest reported in 1912 that the main concern for Japanese parents was that their daughters' marriage possibilities would diminish, disrupting their expected gender roles. ${ }^{65}$ Despite these counter pressures, Takeda continued to think about undergoing baptism. Interested in religious questions, she organized reading groups to discuss theological questions and was fascinated to find missionary teachers sometimes participated as equals with the students, which was unthinkable in traditional Japanese schools. Convinced that Christianity could redeem humans from sin and allow her to transcend narrow-minded Japan and leap into a broader world, Takeda decided to receive baptism in 1938, when militarism and national mobilization were growing because of the second Sino-Japan war. ${ }^{66}$ This time, Takeda's mother opposed the idea for fear that she would become a target for persecution and urged Takeda to postpone the decision for at least another year. Yet, she told her that once decided, she should stick to her decision no matter what may happen. ${ }^{67}$ Takeda, without waiting for a year, received baptism in March 1938.

The timing of March 1938 for Takeda's conversion was especially unfavorable. During the previous year, there were many ominous developments suggesting increasing restrictions on academic freedom for Christians, including the Doshisha University president's resignation. ${ }^{68}$ Responding to anti-Christian suspicions, Kobe College, as explained above, voluntarily received the Imperial Portraits in December 1937. It was in this political context that Takeda decided to receive baptism. One month later, in April 1938, she gained election as YwCA president at Kobe College and, as a consequence of her outstanding leadership, she became chairman of the National Student YwCA Council. Thus, Takeda suddenly entered the national and international scenes of political turmoil. These roles trained her with organizing and leadership skills and connected her to the transnational Christian missionary networks. Originally founded in 1905, the Japan YWCA had joined various international ecumenical networks, including the World YwCA and the World Student Christian Federation

64 Noriko Kawamura Ishii, American Women Missionaries at Kobe College, 1873-19og: New Dimensions in Gender (New York and London: Routledge, 2004), 129-31.

65 Ibid., pp. 145-46, 170, 188-92.

66 "Takeda Kiyoko san shisoshi ka (shonen jidai)" ["Takeda Kiyoko: A Social Thought Historian"], Asahi Shimbun [Asahi Newspaper], Hiogo chiho ban [Hiogo Regional Edition], 13 February 1993, p. 28.

67 Takeda, Deai, pp. 14-15.

68 Cho, Hachiro Yuasa, pp. 32-39; Dohi Akio, Nihon purotesutanto kyo shi [Japan Protestant Christian History], Second Edition (Tokyo: Shinkyo shuppan, 1997), 366-68. 
(WSCF) and their interactions fostered an international outlook among students. ${ }^{69}$

During the late 1930s, the main theme of the Japan YwCA was considering what Christian women should do when war was imminent. Christian women struggled to meet two contradictory goals - to promote conversations with Christian women around the world for peace and to support the home front under the Japanese government's national mobilization policy of September 1937. Takeda's chief responsibility as chairman of the national Student YWCA Council was to plan and make the 1938 Gotemba summer meeting successful. Here, Takeda encountered two important role models, Yuasa Hachiro, the liberal Christian scholar who had resigned from the Doshisha University presidency the previous year, and Hikaru Shizue, who took leadership roles at the Japan YWCA from around 1930 to her death in 1950. Takeda respected Hikaru as her mentor and as a lay prophet who had special talent in reaching ordinary Japanese people. ${ }^{70}$ She especially admired Hikaru's flexible interpretations of the meaning of Bible teachings that would meet the contemporary social reality for Japanese Christians.

The central theme of the 1938 Gotemba summer meeting was the "Unity in Christ" of "young spiritual leaders in this critical state of wartime Japan."71 Yuasa Hachiro's lecture titled "How to Live as Christian" inspired Takeda. In it, he acknowledged wartime difficulties, but emphasized "the values of liberty and peace for mankind," ${ }^{\prime 2}$ and was surprisingly cheerful despite "his traumatic experience at Doshisha" only a year before. He said that those who accused him "did not try to understand me but I wish to be the man who understands them."73 Such a drastic leap of imagination where Yuasa maintained his faith and hope even when conversation became impossible stunned Takeda. His simple faith that "God watches over me," she understood, inspired his creative imagination. "With God, there is nothing to fear," Yuasa declared. "We just keep walking with God."74 His compelling "imagination through difference" lingered in Takeda's mind and became a significant model for her in facing later challenges. But Takeda was even more impressed when DeForest strongly supported her idea to invite Yuasa as the keynote speaker

\footnotetext{
69 Takeda Kiyoko, "Kaisetsu" ["Introduction"], Joshi seinen kai, bessatsu, fukkokuban [YwcA Periodical, Supplementary Volume, Reprinted Edition] (Tokyo: Fuji shuppan, 1994), 3-10.

$70 \quad$ Ibid., pp. 7-9.

71 Joshi seinen kai [YwcA Periodical] 35, no. 5 (May 1938): 24.

72 Joshi seinen kai 35, no. 9 (September 1938): 24-26.

73 Cho, Hachiro Yuasa, pp. 39-41.

74 Quoted in ibid., p. 41.
} 
for the Kobe College YwCA meeting, saying that "Dr. Yuasa was one of her most respected friends." ${ }^{.5}$ Takeda described DeForest as "a Puritan missionary who was deeply rooted in Japan," an exceptional missionary. What deeply moved Takeda was DeForest's character and faith that God assigns every individual with a special mission that nobody else could fulfill. ${ }^{76}$ DeForest became Takeda's life-long mentor and a role model in fighting against a suspicious state and crafting cosmopolitan Christian visions as a Japanese Christian.

Owing to her outstanding leadership in the Gotemba meetings, organizers selected Takeda as a delegate of the Japan YwCA to attend an Amsterdam meeting in summer 1939. Rejoicing upon receiving this news, DeForest quickly arranged in May 1939 for Takeda "to take an Olivet Fellowship after the Amsterdam Conference" so that she could travel directly to the United States. ${ }^{77}$ It seems likely that she knew war was imminent and did not want Takeda to miss this important opportunity. ${ }^{78}$ The trip to Amsterdam initiated Takeda's travels in Asia, Europe, and the United States from July 1939 to June 1942 that became a transformative experience for her. She received the "gift" of her life- to pursue the question of how Japanese Christianity should come to terms with war. Her travels to Amsterdam along the imperial route of European colonial outposts from Shanghai to Aden (present Yemen), Cairo, and Alexandria became shocking encounters with what Takeda labeled as "dark Asia." In Shanghai, Chinese YwCA Christian women took her silently to the site of Japanese military aggression called the "city of death," unknown to Takeda because of military censorship. Appalled, Takeda was stricken with guilt. Her travels through Penang, Singapore, Colombo, and Saigon also shocked Takeda, as she saw the stark contrast between the beautiful Western housing and the miserable state of the indigenous peoples in severe poverty. Upon Takeda's arrival in the European city of Naples, the image of Asia in inexpressible darkness, poverty, and bitterness lingered for her. ${ }^{79}$

At the Amsterdam Conference, Takeda received more difficult news. There, she learned how many countries around the world hated her country of Japan. Takeda's most traumatizing experience came when she spoke to a Chinese woman delegate in hope of becoming friends, but was rejected outright. "If you

75 Ibid., p. 40.

76 Takeda, Deai, pp. 22-23.

77 DeForest to Searle, 30 May 1939, Kobe, folder 4, АвC76, АвсFм papers, box 1, HLHU.

78 Author interview with Takeda, 26 April 2013, Kawasaki, Japan.

79 Takeda, Deai, p. 29; Takeda Kiyoko, Watashitachi to sekai [Us and the World], Nineteenth Edition (Tokyo: Iwanami shoten, 2013), 2-4. 
want friendship with me," her counterpart said, "return to Japan and make efforts so that the dreadful Japanese army will leave China." After first feeling like the woman had closed a door in her face, Takedo soon realized the validity of the rejection and how it was "a gift" for her lifetime learning. ${ }^{80}$ In this reaction, she applied Yuasa's lesson of trying to understand the Chinese woman even though the woman would not understand her, an attempt at exercising imagination through difference. This was a difficult task, however. Takeda wrote to DeForest that she spent hours in "lonely agony." Other participants reported to DeForest how bravely Takeda spoke despite the handicap of her inadequate English. On the question of how Japanese Christians should act, she "uttered her conviction" that "identification with their [own] nation whether in suffering or effort or success is God's will for them." ${ }^{81}$ Even in search of cosmopolitan ecumenism, Japanese identity was significant for Takeda. As a delegate from a widely hated country, she decided it was necessary to challenge imagination through difference to craft a Japanese Christianity that could deal with the social reality of war. Accordingly, her missionary trip to Amsterdam was traumatizing, but also transformative for her as she confronted Japanese military atrocities and experienced personal rejection - forcing her to consider her responsibilities as a Japanese Christian in helping to shape the world's future.

In fall 1939, after crossing the Atlantic, Takeda began her study at Olivet College in Michigan as an exchange student from Kobe College. There, she studied religious philosophy and Christian morality, and the thoughts of Thomas Aquinas, a $13^{\text {th }}$ Century theologian who synthesized Hebraism and Hellenism. Her professor at Olivet thought so highly of her that he arranged for her to study subsequently with renowned theologian Reinhold Niebuhr at the Union Theological Seminary. ${ }^{82}$ Niebuhr's neo-orthodox Christian realism had a significant impact on Western theology and politics beginning in the late 1920s. Believing that humans were sinful, Niebuhr supported U.s. entry into war, arguing that it was a Christian obligation to stop Nazi aggression. Niebuhr's concept that the history of Western thoughts flowed and ebbed with the two major currents of renaissance and reformation contesting and conversing inspired Takeda.

\footnotetext{
8o $\quad$ Takeda, Deai, p. 3 .

81 Joshi seinen kai 36, no. 4 (April 1939): 5-8; DeForest to Friends of Kobe, 10 November 1939, vol. 61, ABC16.4.1, ABCFM papers, HLHU.

82 Takeda, Deai, pp. 39-44; Vanessa Ward, "Journeys in Thought: Takeda Kiyoko and the Promotion of U.S.-Japan Intellectual Exchange," Asian Cultural Studies 39 (March 2013): $79-89$.
} 
In response, she began to shape what would become her life-long work as a scholar to explore the contestations or conversations between Christianity and Japanese social thought in past and present. ${ }^{83}$ Thus, her three-year study in the United States broadened Takeda's perspectives in her quest for ecumenical Christianity that would fit Japan and other Asian countries.

When the United States and Japan went to war in December 1941, Takada faced the question of whether to return to Japan or not. Niebuhr volunteered to be her guarantor so that she could stay in the United States, whereas the Japanese government sent her a telegram requesting her return. With "a strong feeling I would lose something important in my heritage unless I experienced the scourge of war first-hand," Takeda decided to return "to maintain [her] Japanese identity." ${ }^{4}$ In contrast, Yuasa, who at that time was also in New York after attending the Madras International Missionary Conference, decided to stay. "Do what I can do here," he decided, despite the fact that his wife and his sickly child were waiting for his return in Japan. Yuasa joined The New York Church Committee for Japanese Work and visited Japanese Americans in the internment camps during wartime, becoming committed to pursue "an 'intereligious' and 'interracial' way of thinking for the rest of his life." 85

Upon her return to Japan in the summer of 1942, Takeda assumed the position of the secretary of National Student YwCA Council. She immediately was surprised to find even Protestant churches and the YWCA mobilized into war effort. After three years of study abroad, Takeda found herself at odds with those surrounding her, because people appeared silent. Not only was the national mobilization for war efforts already in place, but she herself had changed. As Sheldon Garon explains, in 1939, the Diet had enacted the Religious Organizations Law (shukyo dantaiho) that gave the state "unprecedented powers to regulate religious bodies and organizations" so that they were "virtually conscripted" into the service of Japan's national polity (kokutai) of the cult of the emperor. ${ }^{86}$ In July 1940, military police investigated the Salvation Army on espionage charges and imprisoned members of the Holiness Church. To ensure survival, different Protestant denominations decided to conform to the Religious Organizations Law and merged into the interdenominational

83 Takeda, Deai, pp. 47-48, 52-54; Takeda Kiyoko, "Rainhorudo niba" ["Reinhold Niebuhr"], Riso [Ideals] 24 no. 1 (December 1949): 10-18.

84 Takeda, Deai, pp. 55-56; Cho, Hachiro Yuasa, p. 59; Author interview with Takeda, 26 April 2013, Kawasaki, Japan.

85 Cho, Hachiro Yuasa, pp. 52-59.

86 Sheldon Garon, Molding Japanese Minds: The State in Everyday Life (Princeton, NJ: Princeton University Press, 1997), 84-87; Dohi, Nihon purotesutanto kirisutokyo shi, pp. 341-64. 
organization of the United Church of Christ in Japan in June 1940. Moreover, by April 1941, the government dissolved women's college YWCAs across Japan, reorganizing them into war patriotic associations and renamed the Japan YWCA student department. ${ }^{87}$ In addition, to adhere to the Religious Organizations Law, Japan YMCA and Japan YwCA also became part of the United Church of Christ in Japan, and the government gradually mobilized the whole organization into the war effort. ${ }^{88}$

It was in this authoritarian context that Takeda returned. When she arrived in Yokohama on 20 August 1942, Hikaru Shizue, the general secretary of Japan YWCA, greeted her at the port and asked her to take the position of the secretary of Japan YwCA student department, to which Takeda consented. Takeda began attending council meetings in September 1942, and actively engaged in discussions on how to help students from the women's college YwCAs that no longer existed. Takeda, who had become familiar with college life in the United States, could not quite understand why Japanese remained silent. Perhaps because of such behavior, her colleagues at Japan YwCA, who found Takeda's behavior strange, nicknamed her Urashima san. Urashima san was the name of a fisherman in a Japanese folk tale who travelled to an enchanted world deep under the sea, only to find himself a total stranger when he returned home because either he himself or the environment had changed drastically. ${ }^{89}$

In July 1943, the Tokyo metropolitan police department suddenly summoned Takeda to explain the assistance she had provided to a group of Chinese students in a nearby dormitory who had failed to leave the country before the war began. Prepared for arrest, she packed her belongings in a suitcase and asked her colleague to bring it if necessary. Remembering how DeForest held steadfast when she supported inviting Yuasa to be the keynote speaker for the Kobe College YwCA meeting in 1939, Takeda said forcefully that she had helped the students personally and the Japan YwCA was not involved. The middleaged officer who examined her was unexpectedly understanding and smilingly warned her that she should be careful of her speech and action because the special higher police probably brought the case in the hopes of advancing their own careers. ${ }^{90}$ Here, Takeda applied DeForest's lesson to be firm and pragmatic

87 Joshi seinen kai 39, no. 2 (February 1942): 9; Kobe jogakuin (ed.), Kobe jogakuin hyakunenshi: sosetsu, pp. 250-53.

88 Takeda, Deai, p. 6o; Joshi seinen kai 40, no. 1 (January 1943): 1-6.

89 Takeda, Deai, pp. 6o-61.

$90 \quad$ Ibid., pp. 62-64; Yamamoto Arihira, "Shiso shi gakusha,Takeda kiyokoshi Chigau bunka soncho wo" ["Ms. Takeda Kiyoko, a scholar in the History of Social Thoughts Respecting Different Cultures"], Sengo to watashi, Sengo zo nen intabyu [Postwar and Myself, 
in her pursuit of conversations across lines of difference. At the same time, Takeda found hope for the future of Japan, which she would continue to seek in her observations.

In April 1944, the YwCA student department sent Takeda as an instructor to the Hitachi steel factory in Shizuoka to examine the labor conditions of the female factory workers. Again, she was stunned to find the women college students obedient and silent in working under harsh conditions. They tolerated demeaning treatment, including food shortage, poor hygiene and long working hours. Takeda succeeded in improving the working schedule after submitting a survey report to the director with a graph showing women workers losing weight. ${ }^{91}$ Both the student workers and managers tried to sneak extra food for themselves even as their colleagues were starving. They told lies but did not regard it wrong because the government had deceived them and everything surrounding them was full of falsehood. They knew that the military airplanes were more fragile than announced because they used less material when they were building their framework. ${ }^{92}$ Takeda also learned that the factory operators curtailed freedom of speech and enforced strict thought control. They regarded her discussion of peace in lectures as dangerous, she learned, when listeners secretly reported this to the police. In response, the police checked her belongings, confiscating books, and visited students' homes for further investigation. ${ }^{93}$

After her observations at the factory, Takeda came to a new understanding of Japanese behavior. She later explained this phenomenon as the dual structure of Japanese consciousness and named it "the image of humans in shells." Takeda analyzed this as a form of resistance because she thought that both the workers and managers had two faces, the shell and the inner self, and scarcely would express their inner self. ${ }^{94}$ She soon realized, after spending months

Postwar 7o-Year Interviews], Nihon keizai shimbun [Japanese Economics Newspaper], 31 July 2015, https://www.nikkei.com/article/DGXMZO8937699oW5A710C1oooooo/ (accessed 1 September 201).

91 Takeda, Deai, pp. 64-66.

92 Takeda Kiyoko, "Kojo ni mita uso to kaigara ningenzo," ["Lies and Images of Humans in Shells at Factory"], Shiso no kagaku [Science of Thought] 1, no. 8 (July 1953): 39-41.

93 Takeda Kiyoko, "Haisen karano shuppatsu: kaikon wo mune ni heiwa eno michi wo saguru" ["Departure from War Defeat: In Pursuit of Peace, Filled with Remorse"], NHK TV program, 16 May 2014, Post-war Oral History Archives, http://cgi2.nhk.or.jp/archives/ shogenarchives/postwar/shogen/movie.cgi?das_id=Doo12100086_ooooo (accessed 16 August 2016).

94 Takeda Kiyoko, "Kaigara ningen zo" ["Images of Humans in Shells"], in Gendai tetsugaku dokuhon [Modern Philosophy Reader], Shiso no kagaku kenkyukai [Science of Thought Research Group ], ed. (Tokyo: Kawade shobo, 1954), 76-82. 
with her students and factory managers, that these Japanese were neither docile nor blindly obeying the rules but were exercising freedom of imagination in formulating penetrating observations, although they remained silent. They instinctively knew Japan's defeat was imminent, but such imagination appeared on the surface only when they saw what they believed to be unthinkable taking place in their everyday life. Manifestations of this pattern took place when it rained on 3 November 1944, the national holiday celebrating the Meiji Emperor's birthday, and when rumors spread that the holy torii gate of the Ise shrine recently had collapsed. When the unthinkable happened, folk beliefs told them that the divine was sending them ominous messages.

Such was the concept of "the image of humans in shells" that Takeda shaped to explain the fundamental dilemma of Japan. For Takeda, this explained why Japan could not avoid war, but was also a sign of hope that inherent in all the Japanese was the potential of unexpected flexibility and freedom of imagination. In her postwar discussions, Takeda would develop further this concept, arguing that the Japanese would need to break this "shell" to achieve true freedom. ${ }^{95}$ In sum, Takeda's evolution as a missionary protégé into an ecumenical leader in Japan YWCA during the wartime years of 1934 to 1944 was a journey of continuous challenges. Owing to prewar mission school education, she acquired Christian faith, English proficiency, and access to transnational missionary networks that allowed her to explore imagination through difference. By the end of the war, Takeda identified the "image of humans in shells" as a clue for her postwar search to realize a cosmopolitan vision of Christian faith for Japan in Asia.

As this article has shown, both DeForest and Takeda managed to pursue imagination through difference in crafting new visions of Christian cosmopolitanism during the difficult years of World War II on both sides of the Pacific. For each, the factors of parental influences, linguistic skills, and transnational missionary networks became instrumental in allowing them to confront their challenges. The visions they created during the 1930s and 1940s, however, manifested some differences in focus, but they shared the ultimate goal to craft aspirational cosmopolitanism rooted in Christian faith. DeForest's statement that her identity was Christian and "supernational" as the two nationstates headed to war implied that her vision transcended race and state, yet she perceived Christianity as the ultimate religion. Takeda, on the other hand, transcended race, yet upon the outbreak of war, she reverted to her 
Japanese identity, returning home to imagine how Christianity might help Japan recreate itself following the defeat of its imperial ambitions. Yuasa, who emerged a key influential figure for both DeForest and Takeda, exemplified yet another vision. His version of Christian cosmopolitanism transcended race, state, and religion, manifesting a much larger scope of imagination grounded on the vision that all religions stemmed from one unified origin. Yuasa therefore relied on an inter-religious and an inter-racial way of thinking in his pursuit of egalitarian relationships.

When the International Christian University (ICU) opened in 1953 as the first postwar ecumenical Christian college in Japan, with funding from both Japanese and American sources, it was no coincidence that Yuasa served as the first president and Takeda a professor. DeForest had returned to Kobe College only briefly between 1947 and 1951. Together, they founded the Asian Cultural Committee in 1958, as a quest for cosmopolitanism in which the East and the West and the former colonizer Japan and the former colonized Asia could participate on a basis of equality. Receiving funding from the HarvardYenching Institute, they conducted research on the impact of Christianity on Asian cultures. ${ }^{96}$ Agreeing with Yuasa' s vision to make the university "international, interracial, intercultural and coeducational" and providing scholarship to Chinese students from the beginning, such pioneering work in Asian studies also was a prime example of efforts at reconciliation to the victims of Japanese wartime aggression in Asia.

When the ashes of DeForest arrived for burial in Japanese soil in 1973, Takeda had become a busy leader devoted to spreading ecumenical cosmopolitanism around the world in her positions both as a scholar, heading the Institute of Asian Cultural Studies at ICU (the 1971 successor to the Asian Cultural Committee), and as president of the World Council of Churches, representing the Asian continent, from 1971 to 1975 . DeForest, fulfilling her commitment as a lifetime missionary to serve the Japanese people, but not to have them serve her, chose to send her ashes to Sendai for burial with her parents at the Christian grave site of the Rinnoji, a Zen temple. Significantly, the location itself epitomized DeForest's ecumenical cosmopolitanism. ${ }^{97}$ DeForest herself carefully designed the tombstone and its location, which rests diagonally on top of the hill to face the Pacific. ${ }^{98}$ Here rests Charlotte B. DeForest, who was a foremost

96 Kiyoko Takeda Cho, "Activities of the Committee on Asian Cultural Studies," Asian Cultural Studies 2 (September 1960): 93-96.

97 Author interview with Takeda, 6 June 2013, Kawasaki, Japan.

98 DeForest to the treasurer, DeForest Memorial Church, Sendai, Japan, 14 October 1953, folder 22, DeForest Papers, box 2, YDSL. 
mediator between the two cultures. She passed on her vision of Christian cosmopolitanism successfully to Takeda, who in turn would seek a Japanese vision of aspirational cosmopolitanism that would transcend emerging differences in the context of the Cold War.

\section{Selected Bibliography}

\section{Primary Sources}

Cho, Takeda Kiyoko. "Activities of the Committee on Asian Cultural Studies." Asian Cultural Studies 2 (September 1960): 93-96.

DeForest, Charlotte B. The Evolution of a Missionary: A Biography of John Hyde DeForest for Thirty-Seven Year Missionary of the American Board in Japan. New York, Chicago, Toronto: Fleming H. Revell Company, 1914.

DeForest, Charlotte B. History of Kobe College. Kobe, Japan: Kobe College, 1950.

DeForest, Charlotte B. The Woman and the Leaven in Japan. West Medford, MA: The Central Committee on the United Study of Foreign Missions, 1923.

Kirisutokyo joshi seinenkai nihondomei [Japan YWCA], Ed. joshi seinen kai [YwCA Periodical], 1938, 1939, 1942, and 1943.

Mission to Japan. American Board of Commissioners for Foreign Missions Archives, 1810-1961 (ABC 1-91). Houghton Library, Harvard University, Cambridge, MA.

Papers of Charlotte B. DeForest. American Board of Commissioners for Foreign Missions Archives, 1810-1961. Houghton Library. Harvard University, Cambridge, MA.

Papers of Charlotte B. DeForest. Sophia Smith Collections. Smith College, Northampton, MA.

Papers of Charlotte B. DeForest. Special Collections. Record Group 178. Yale Divinity School Library, New Haven, ст.

Takeda Kiyoko. Author interviews, 25 April 2013 and 6 June 2013, Kawasaki, Japan.

Takeda Kiyoko. Deai: hito, kuni, sono shiso [Encounters: People, Nation, Thoughts]. Tokyo: kirisutokyo shimbunsha, 2009.

Takeda Kiyoko. "Haisen karano shuppatsu: kaikon wo mune ni heiwa eno michi wo saguru" ["Departure from War Defeat: In Pursuit of Peace, Filled with Remorse"]. NHK TV program, 16 May 2014. Postwar Oral History Archives. http://cgi2.nhk.or.jp/ archives/shogenarchives/postwar/shogen/movie.cgi?das_id=Doo12100086_00000 (accessed 16 August 2016).

Takeda Kiyoko. "Kaigara ningen zo" ["Images of Humans in Shells"]. Gendai tetsugaku dokuhon [Modern Philosophy Reader]. Shiso no kagaku kenkyukai [Science of Thought Research Group], Ed., 76-82. Tokyo: Kawade shobo, 1954.

Takeda Kiyoko. "Kojo ni mita uso to kaigara ningenzo" ["Lies and Images of Humans in Shells at Factory"]. Shiso no kagaku [Science of Thought] 1 No. 8 (July 1953): 39-41. 
Takeda Kiyoko. Watashitachi to sekai [Us and the World]. Nineteenth Edition. Tokyo: Iwanami shoten, 2013 .

"Takeda Kiyoko san shisoshi ka (shonen jidai)" ["Takeda Kiyoko: A Social Thought Historian"], Asahi Shimbun [Asahi Newspaper], Hiogo chiho ban [Higo Regional Edition], 13 February 1993, p. 28.

Yamamoto Arihira. "Shiso shi gakusha,Takeda kiyokoshi Chigau bunka soncho wo" ["Ms. Takeda Kiyoko, a scholar in the History of Social Thoughts Respecting Different Cultures"], Sengo to watashi, Sengo 70 nen intabyu [Postwar and Myself, Postwar 70-Year Interviews], Nihon keizai shimbun [Japanese Economics Newspaper], 31 July 2015, https://www.nikkei.com/article/DGXMZO8937699oW5A710C1000ooo/ (accessed 1 September 2016).

\section{Secondary Sources}

Bose, Sugata and Kris Manjapra, Eds. Cosmopolitan Thought Zones: South Asia and the Global Circulation of Ideas. New York: Palgrave Macmillan, 2010.

Cho, Kiyoko Takeda. Hachiro Yuasa: The Hopes and Challenges of a Christian Educator in Japan. Norwalk, Ст: East Bridge, 2008.

Davidann, Jon Thares. Cultural Diplomacy in U.S.Japanese Relations, 1919-1941. New York: Palgrave Macmillan, 2007.

Dohi Akio. Nihon purotesutanto kyo shi [Japan Protestant Christian History]. Second Edition. Tokyo: Shinkyo shuppan, 1997.

Garon, Sheldon. Molding Japanese Minds: The State in Everyday Life. Princeton, NJ: Princeton University Press, 1997.

Gluck, Carol. Japan's Modern Myths: Ideology in the Late Meiji Period. Princeton, NJ: Princeton University Press, 1985 .

Hirobe, Izumi. Japanese Pride, American Prejudice: Modifying the Exclusion Clause of the 1924 Immigration Act. Stanford, CA: Stanford University Press, 2001.

Ishii, Noriko Kawamura. American Women Missionaries at Kobe College, 1873-19o9: New Dimensions in Gender. New York and London: Routledge, 2004.

Kobe jogakuin [Kobe College], Ed. Kobe jogakuin hyakunenshi sosetsu [Centennial History of Kobe College: General]. Kyoto: Kawakita insatsu, 1976.

Komagome, Takeshi. "Senjika doshisha saiko: teikokushi no shiten kara," ["Reconsidering the History of Doshisha during the 1930s: From the Perspective of Japanese Imperial History"]. Doshisha University Institute for Humanities and Social Sciences, Ed. Kirisutokyo shakaimondai kenkyu [The Study of Christianity and Social Problems] 62 (December 2013): 103-34.

Motoi Yasuhiro. "Niijima jo to J.H. Deforesuto: rattorando kara sendai e," ["Niijima jo and J.H. DeForest: From Rutland to Sendai"], Kirisuto kyo shakai mondai kenkyu [The Study of Christianity and Social Problems ] 42 (July 1993): 56-82. 
Nakai, Kate Wildman. "Coming to Terms with 'Reverence at Shrines': The 1932 Sophia University-Yasukuni Shrine Incident." In Kami Ways in Nationalist Territory: Shinto Studies in Prewar Japan and the West. Bernhard Scheid, Ed., 109-53. Vienna: Austrian Academy of Sciences, 2013.

Ngai, Mae M. Impossible Subjects: Illegal Aliens and the Making of Modern America. Princeton, NJ: Princeton University Press, 2004.

Steele, M. William. "Great Northern Famine of 1905-06: Two Sides of International Aid." Asian Cultural Studies 39 (March 2013): 4-15.

Takeda Kiyoko. "Kaisetsu" ["Introduction"]. Joshi seinen kai, bessatsu, fukkokuban [YWCA Periodical, Supplementary Volume, Reprinted Edition]. Tokyo: Fuji shuppan, 1994.

Takeda Kiyoko. "Rainhorudo niba" ["Reinhold Niebuhr"]. Riso [Ideals] 24 No. 1 (December 1949): 10-18.

Takenaka Masao. Shi Bi Deforesuto no shogai: bi to ai no tankyu [The Life of C.B. DeForest: In Quest of Beauty and Love]. Osaka: Sogensha, 2003.

Thal, Sarah. "A Religion That Was Not a Religion: The Creation of Modern Shinto in Nineteenth-Century Japan." In The Invention of Religion: Rethinking Belief in Politics and History. Derek Peterson and Darren Walhof, Eds., 100-14. New Brunswick, NJ: Rutgers University Press, 2002.

Toda Tetsuko. "Jon. H. Deforsuto to saikyo jikkai shinron." [“John H. DeForest and The True Argument on the Ten Commandments"], Yamanashi kenritsu joshi tankidaigaku kiyo [Bulletin of Yamanashi Prefectural Junior College for Women] 31 (March 1998): 31-38.

Ward, Vanessa. "Journeys in Thought: Takeda Kiyoko and the Promotion of U.s.-Japan Intellectual Exchange." Asian Cultural Studies 39 (March 2013): 79-89. 